Sergey Chirun

\title{
Проблемы и технологии взаимодействия государства и институтов ислама: опыт России и Евросоюза
}

В представленном докладе автором предлагается сравнительный анализ ислама в государствах Евросоюза и России.

Автор показывает взаимосвязь между процессом исламизации и радикализацией политического ислама. Вместе с тем, по мнению автора, исламистские проекты не способны выступить глобальным объединяющим фактором, поскольку важнейшими составляющими политического поведения мусульман являются различное истолкования Корана, этничность и клановость, а также отношение к модернизации и секуляризации. Показано различие в подходах к феномену власти, существующее в суннизме и шиизме. Тем не менее, радикализация политического ислама может стать причиной актуализации религиознополитических противоречий, и таким образом исламистский фактор может сыграть свою дестабилизирующую роль в условиях глобализации. Поэтому, международному сообществу следует координировать свои усилия в осуществлении системного противодействия радикальному исламизму. В процессе дерадикализации политического ислама допустима реализация PR-кампаний, направленныхх на сближение ислама и христианства, поиск точек соприкосновения между религиями.

За последние два десятилетия мусульмане россии обозначили своё полноценное присутствие в мировой мусульманской Умме. Однако, разнообразие этнических культур между крупнейшими по численности мусульманскими этносами, с одной стороны - татарами и башкирами, a c другой народами Северного Кавказа обозначили существенные расхождения ${ }^{1}$. Так, в России существуют два исламских ареала, каждый из которых, имеет свою специфику. Поэтому, можно сказать, что Российского ислама, как гомогенного феномена сегодня не существует

Крупнейший мусульманский этнос - татары составляют 5,5 млн чел., и компактно проживают в Татарстане и Башкирии. Также татары проживают составляя меньшинство на Южном Урале и Сибири и ещё в ряде регионов ${ }^{2}$. Особую популярность у татарских интеллектуалов приобрела

${ }^{1}$ А.Ю. Хабутдинов, Развитие мусульманской общины Татарстана в 2016 - начале 2018 г., «Ислам в современном мире» 2018, Т. 14, № 2, с. 25-42, https://doi.org/10.22311/2074-1529-201814-2-25-42, дата обращения 5.09.2019.

2 Л.В. Сагитова, Ислам в конструировании регионального политического дизайна современного Татарстана, «Вестник Российского университета дружбы народов» 2018, Т. 20, № 3, c. 313-322. 
метафора: «Татары - „передаточное звено“, или „мост“ между Западом и Востоком». Эти формулы декларируются официальной властью республики в качестве основы стратегии развития поликонфессиональной территории. Вторые по численности - башкиры - 1,6 млн.

Постсоветская история Российской Федерации продемонстрировала их значимость в формировании политической идентичности российских регионов, особенно в национальных республиках. Так, для многих республик с мусульманским населением ислам становится одной из важнейших составных в повседневной жизни, а для местных элит - элементом формирования политики идентичности региона.

В 7 субъектах РФ мусульмане преобладают: в Ингушетия - 98\%, Чечня - 96, Дагестан - 94, Кабардино-Балкария - 70, Карачаево-Черкессия - 63, Башкортостан - 54,5, Татарстане - 54\%. В 9 субъектах их количество превышает 10\%: в Адыгее - 21\%, Астраханской области - 26, Северной Осетии - 21, в Оренбургской области - 16,7, в Ханты-Мансийском автономном округе - 15, Ульяновской области - 13, в Челябинской - 12, в Тюменской - 10,5, в Республике Калмыкия - 10\%. В Москве, по словам Председатель Совета муфтиев России Равиля Гайнутдина, два млн. масульман. К мусульманам-гражданам РФ следует добавить мусульман-мигрантов. По самым скромным оценкам в России - 1,5 млн. выходцев из Центральной Азии ${ }^{3}$.

Суммируя граждан-мусульман и мигрантов, мы получаем число примерно в 20-25 млн.

Кого можно считать мусульманином? Если исходить из того, что им является только тот, кто регулярно совершает предписанные исламом обряды и запреты, то таковых, по разным оценкам, окажется всего 8-9 млн. или даже меньше. Но если исходить из критерия самоидентификации, то два десятка миллионов в России - это реальность.

Мусульмане России принимают участие и одновременно находятся под воздействием процесса «глобализации ислама». Осознание своей принадлежности к мировой умме вступает в противоречие с охранением собственной этнокультурной версии ислама. «Новый ислам», ассоциируется с религиозным радикализмом в то время как традиционный ислам казался деполитизированным, был погружен в внутрирелигиозные заботы ${ }^{4}$. Под традиционным исламом понимается суннитский ислам двух утвердившихся среди мусульман России религиозно-правовых школ - ханафизма, к которому принадлежат татары, башкиры и часть

\footnotetext{
${ }^{3}$ М.А. Магомедова, Проявления религиозно-политического экстремизма в Республике Дагестан и меры противодействия, «Власть» 2017, Т. 25, № 12, с. 171-177.

${ }^{4}$ P.М. Мухаметзянова-Дуггал, Религия и власть в России XX-XXI вв.: три модели государственно-конфессиональных отношений, «Власть» 2017, Т. 25, № 6, с. 100-104.
} 
кавказских мусульман и шафиизма, распространенного в Дагестане и Чечне, а во-вторых, суффизм, (тарикатизм) в Дагестане, Чечне и Ингушетии ${ }^{5}$. Тогда как среди татар и башкир влияние суфиев несравненно меньше.

Сейчас «новый ислам» разделяет идею конфликта цивилизаций, а традиционный - считает её ложной. Однако сближение позиций «нового» и традиционного ислама - феномен объективно неизбежный: сторонники обоих направлений считают ислам первостепенным регулятором общественных отношений, что может быть обеспечено лишь их контролем над властью или установлением собственного правления.

В России имеют место попытки внедрения исламских принципов в банковское дело. Ислам проникает в область страхования, и в Татарстане уже действует программа «Идель-Хадж», помогающая мусульманам накопить средства для совершения хаджа.

В Татарстане с 2005 г. исламский налог закят (один из пяти столпов ислама) можно выплачивать через «светские» банки. По мнению сторонников реконструкции исламской налоговой системы, обязательность уплаты федеральных, региональных и местных налогов «не отменяет и не умееньшает выплату закята, поскольку у них разное предназначение».

В Духовном управлении мусульман Европейской России открыт специальный отдел, занимающийся прозводством и продажей халялных продуктов, разработаны нормативы их производства. Их сертификацию осуществляют комитеты «Халяль», которые действуют в Татарстане, Башкортостане, Мордовии, Чечне, Карелии, а также еще в 6 областях российской федерации

В Казани регулярно проводится Международный фестиваль мусульманского кино «Золотой Минбар».

Де-факто в РФ легализовалась и поощряется духовенством, но и некоторыми политиками - полигамия. Среди них президент Чечни Рамзан Кадыров, бывший президент Ингушетии Руслан Аушев, глава Духовного управления мусульман Поволжья Мукаддас Бибарсов, глава Центрального Духовного управления мусульман Талгат Таджутдин.

Пятничные молитвы все чаще посещаются бизнесменами и политиками, стремящимися подтвердить в глазах верующих свою приверженность исламу.

Имевшие место попытки Кремля выстроить «исламскую вертикаль» уступили место пониманию того, что ислам в России в организационном

${ }^{5}$ Ю.Д. Джабраилов, Ислам и этничность в Дагестане: особенности взаимовлияния (на основе экспертного опроса), «Власть» 2017, Т. 25, № 11, с. 102-106.

${ }^{6}$ Р.М. Мухаметзянова-Дуггал, Трансформация государственной конфессиональной политики в Республике Башкортостан, «Власть» 2017, Т. 25, № 9, с. 78-86. 
плане полицентричен, не может концентрироваться вокруг одного института и иметь одного лидера.

Показательно, что на Северном Кавказе растущая в последние годы привлекательность тарикатского ислама объяснима его растущей политизацией ${ }^{7}$. А также тем, что он отвечает запросам современной культуры. Важным фактором, способствовавшим успеху суфийских движений, стало то обстоятельство, что суфизм был в значительной степени отделен от ислама как такового, с которым, особенно в последние десятилетия, европейцы склонны связывать различные негативные явления. В Чечне он обрел привлекательность в глазах молодого поколения, когда его стал продвигать Рамзан Кадыров.

Молодежь до 30 лет составляет на Северном Кавказе в среднем две трети населения,

Если немусульманское население России ежегодно сокращается, то доля мусульман, прежде всего выходцев с Кавказа соответственно возрастает (тогда как для татар и башкир нехарактерен рост численности) ${ }^{8}$.

В России сейчас нет религиозного конфликта по линии православие-ислам, но сохраняется напряженность между федеральным центром и Северным Кавказом. И «кавказофобия», представляет куда большую проблему, чем конфликт религий. Именно Северный Кавказ служит главным источником исламистской и сепаратистской напряженности.

Неизбежно будет нарастать поток мигрантов-мусульман из Центральной Азии и Закавказья. Получается парадоксальная картина: с одной стороны, мигранты оказываются как бы оторванными от ислама, с другой стороны, для них ислам оказывается средством самозащиты от чужого мира. Это, напоминает ситуацию с мусульманами в Европе, где ислам также играет все большую роль среди мигрантов.

Западноевропейские страны обеспокоены проблемой интеграции иммигрантов-мусульман, т.к. их количество стремительно увеличивалось в последние годы. Ещё в 2008 г. на весенней сессии Парламентской ассамблеи Совета Европы в докладе «Европейские мусульманские общины перед лицом экстремизма» отмечалось, что доля выходцев из исламских стран в Евросоюзе к 2050 г. может составить треть или даже половину населения EC 9 . При этом в ближайшие 20 лет основными странами проживания мусульман в Европе будут Великобритания, Гер-

\footnotetext{
${ }^{7}$ К.С. Васильцов, В лабиринтах смысла: суфизм, неосуфизм, нью-эйдж, «Ислам в современном мире» 2018, Т. 14, № 3, с. 197-214, https://doi.org/10.22311/2074-1529-2018-14-3-197-214, дата обращения 5.09.2019.

${ }^{8}$ А.Ю. Хабутдинов, ор. cit.

${ }^{9}$ Документы, принятые на весенней сессии Парламентской Ассамблеи Совета Европы (14-18.04.2008 г.), http://www.strasbourg-reor.org/?topicid=216, дата обращения 7.09.2019.
} 
мания, Франция, Бельгия, Италия, и Нидерланды. Вместе с тем, в последние годы ситуация осложнилась еще и миграционным кризисом, вызванным гражданскими войнами и вооруженными конфликтами на Ближнем Востоке, что привело к массовому оттоку беженцев из зон боевых действий в страны Европы.

Таким образом, Европа столкнулась с беспрецедентной по своим масштабам и последствиям ситуацией с вынужденной миграцией. Масштабный поток вынужденных мигрантов вызвал коллапс миграционной политики и привел к многочисленным социально-политическим проблемам в странах ЕС. Европейская система предоставления убежища столкнулась как с техническими сложностями идентификации лиц, ищущих убежища, так и с концептуальным вызовом, подрывающим основы ее существования, в т.ч. несостоятельностью идеи мультикультурализма $^{10}$. «Кризис беженцев» в Европе обозначил необходимость изменений как в политических структурах, так и в социальной системе $\mathrm{EC}^{11}$. Переход от мультикультурализма к постмультикультурализму создаёт рамки для обсуждения старой и новой миграции, разнообразия и суперразнообразия, отношений между группами иммигрантов как элементами структуры национального общества и диаспорами как социальными агентами, имеющими транснациональную природу. Постмультикультурализм позволяет устанавливать новые взаимосвязи между национальными и транснациональными траекториями развития, с одной стороны, и фокусировать внимание на паттернах репрезентации идентичности иммигрантов как многомерной, гибридной, подвижной - с другой. Возникающая постмультикультуральная перспектива подразумевает как признание культурного разнообразия, так и сохранение коллективной национальной идентичности.

Сегодня для Европы характерно слияние нескольких миграционных потоков - легальной, нелегальной экономической миграции, а также беженцев - в один мощный поток. Отсюда и такой пестрый национальноэтнический состав: сирийцы, египтяне, ливийцы, нигерийцы, афганцы, пакистанцы и др. Немаловажным будет отметить то, что основная масса мигрантов изначально нацелена на наиболее развитые страны Западной Европы. Это свидетельствует о достаточно высокой степени их информированности относительно условий жизни, качества и «щедрости» социально-экономической поддержки, оказываемой мигрантам

${ }^{10}$ А. Куропятник, М. Куропятник, Постмультикультурализм и культурное разнообразие в эпоху глобализации, «Международные процессы» 2018, Т. 16, № 1, с. 29-39, https://doi.org/10.17994/IT.2018.16.1.52.3, дата обращения 7.09.2019.

${ }^{11}$ Г.И. Гаджимурадова, Проблемы гендерного равенства в мусульманских общинах Eвропь, «Власть» 2017, Т. 25, № 1, с. 136-139. 
и беженцам в той или иной стране ЕС. Продолжается демографический взрыв соседних с Европой исламских странах. Так, население Египта растет на 2 млн. человек в год, оно превысило 96 млн. человек. Страна задыхается от перенаселения, не хватает воды, пригодные для жизни земли составляют лишь 7\% территории. С аналогичными проблемами сталкиваются и другие страны арабского мира, общая численность населения которых составляет свыше 400 млн. человек. В Турции за последние 25 лет население увеличилось с 50 до более 83 млн. человек. Источником высокой рождаемости остаются внутренние районы Анатолии, где население ведет традиционный образ жизни, исповедует консервативный ислам и рожает много детей.

Стоит отметить, что миграционный кризис лишь усилил те противоречия, конфликты, которые давно имели место в европейском обществе. Он обозначил «слабые места» в миграционной, конфессиональной политике, системе национальной безопасности и международных отношений стран $\mathrm{EC}^{12}$.

Согласно концепции «евроислама» (Т. Рамадан, А. Баят, Б. Тиби, Т. Модуд), следует различать принципы ислама и его традиции, поскольку они могут различаться, будучи детерминируемыми историческими и культурными характеристиками каждого народа, а также существующими государственными законами. Таким образом, единство ислама, не исключает множественность культуры. В исламе присутствует как единение, так и многообразие. Поэтому исследователи могут рассуждать о особенностях европейского, канадского, американского, или западного ислама. При этом «европейскость», относится к доминирующей культуре, но сами принципы, изложенные в Коране, неизменно остаются исламскими. Сторонники «евроислама» считают, что арабская культура - не тожественна культуре ислама. По их мнению, сегодня необходимо реформировать ислам, изменив интерпретацию Корана. Иначе говоря, мусульмане, решившие жить а Европе, должны «европеизироваться», не теряя при этом своей идентичности. Но это возможно только при условии принятия ими концепции основополагающих принципов европейских ценностей.

Идеологи политического ислама умело используют слабости западной цивилизации. Многие мусульмане Западной Европы активно принимают участие в общественно-политической жизни стран проживания, занимаются религиозно-просветительской деятельностью, стремятся оказывать влияние на функционирование политической системы, формирование политических институтов и принятие политических

${ }^{12}$ Eadem, Европейские мусульмане и мусульмане в Европе: рядом или вместе?, «Власть» 2018, T. 26, № 2, с. 60-63. 
решений, используя при этом демократические рычаги. Происходит последовательный процесс исламизации стран Западной Европы, сопровождающийся построением параллельных структур власти.

На сегодняшний день процесс исламизации в Западной Европе имеет тенденцию к усилению, что наблюдается в различных сферах государственной политики и общественной жизни. Выделяется вертикальная и горизонтальная исламизация.

«Вертикальная исламизация» - это исламизация институтов государственной власти, протекающая на трех уровнях: муниципальном, региональном и национальном. Она осуществляется в рамках уже существующих политических институтов и сопровождается ростом числа мусульман в составе политической элиты страны ${ }^{13}$.

«Горизонтальная исламизация» - это исламизация относительно автономных и независимых от государства общественных институтов и отношений, направленная на создание в обществе необходимых условий для удовлетворения социальных, экономических, политических и культурных потребностей мусульманского сообщества. Данный тип исламизации характеризуется развитием «горизонтальных связей», созданием исламских общественных институтов и групп давления, оказывающих влияние на государство «снизу».

Вертикальная исламизация предполагает участие мусульман в выборном процессе для занятия должностей в органах законодательной и исполнительной власти, что способствует росту числа мусульман в составе политической элиты страны. В дальнейшем это может привести к лоббированию интересов мусульманского сообщества (или его отдельных групп) на различных уровнях государственной власти. Немаловажное значение имеет политическое участие иммигрантов-мусульман в странах Западной Европы, создаются исламские политические партии: «Европейская арабская лига» (Нидерланды, Бельгия), партия «Ислам» (Бельгия), «Партия исламских демократов» (Нидерланды), «Союз за обновление и справедливость» (Германия), «Партия мусульман Франции» и.тд.

Мусульмане участвуют в выборах разного уровня не только как избиратели, но и кандидаты, а политические партии ведут активное соперничество за их голоса.

В целом, наблюдается рост представительства мусульман в органах государственной власти различного уровня. В ряде западноевропейских стран они входят в состав национальных парламентов и правительств. Наблюдается большая активность мусульман и на выборах местного

${ }^{13}$ В.И. Олейник, «Вертикальная» и «горизонтальная» исламизация Западной Европь в контексте миграционного кризиса, «Власть» 2016, Т. 24, № 5, с. 181-184. 
уровня. Напр., в мае 2016 г. мэром Лондона впервые был избран мусульманин Садик Хан - кандидат от Лейбористской партии ${ }^{14}$.

Самуил Хантингтон отмечает, что исламизация, как правило, происходит сначала в культурном плане, а затем переходит на социальную и политическую сферы. В основе исламизации лежит развитие исламских общественных организаций и взятие под контроль уже существующих учреждений. Исламисты всегда ставили своей целью создание исламского «гражданского общества», которое бы заменяло деятельность слабых институтов светского гражданского общества. Наиболее распространенным методом достижения исламистами своих целей «ползучая исламизация», а именно, создание сети параллельных социальных институтов, которые становятся центрами политической агитации и подготовки исламистских кадров. Стоит отметить, что многие мечети а также исламистские организации Европы финансируются мусульманскими странами: Так, при финансовой поддержке Саудовской Аравии функционируют: Всемирный исламский совет, Исламский центр в Лондоне, Исламские культурные центры в Женеве и Мадриде. В свою очередь, ОАЭ посредством благотворительного фонда «Аль-Мактум» занимается курированием Исламского культурного центра в Дублине, а Парижская соборная мечеть пользуется поддержкой Алжира. Увеличение количества мечетей неоднозначно воспринимается в странах Западной Европы. С одной стороны, строительство новых мечетей отвечает религиозным и культурным потребностям мусульман и соответствует принципам религиозного плюрализма и толерантности, разделяемых большинством населения. С другой стороны, в общественном сознании европейцев формируется мнение, что мечети и минареты несут в себе угрозу исламизации. Так в Великобритании в 2012 г., решением местного совета района Ньюхэм в Лондоне был отклонен проект строительства мегамечети на 10000 человек.

Процесс горизонтальной исламизации может усилить социальные, религиозные и этнокультурные различия и способствовать формированию мусульманских гетто, их радикализации, а также может привести к построению параллельных структур власти. Многие исследователи отмечают появление в европейских городах большого количества районов, закрытых не только для коренных европейцев, но и правоохранительных органов. При этом наибольшая геттоизация мусульман наблюдается в Бирмингеме, Дерби, Брэдфорде, Манчестере, Ливерпуле и др. Таким образом, геттоизация создает благоприятную

\footnotetext{
${ }^{14}$ Мэром Лондона впервые избран мусульманин, лейборист Садик Хан, http://tass.ru/ mezhdunarodnaya-panorama/3265049, дата обращения 7.05.2016.
} 
почву для деятельности радикальных исламистов, которые могут завербовать новых сторонников, используя недовольство, неподконтрольность и обособленность мусульманских гетто.

Одним из наиболее значимых проявлений горизонтальной исламизации выступает создание шариатских судов, что также является результатом деятельности исламистов и направлено на построение параллельных структур судебной власти.

Помимо этого, в странах Западной Европы существуют общеевропейские исламские организации, деятельность которых носит сетевой характер. С одной стороны, они формально отвергают насильственные методы достижения своих целей, но в то же время призывают к введению норм шариата, что в принципе невозможно в рамках существующего законодательства Западной Европы.

На сегодняшний день процесс исламизации в Западной Европе имеет тенденцию к усилению. В этой связи повышается риск радикализации политического ислама. Создание атмосферы страха и неуверенности, вызванное миграционным кризисом и террористическими актами, усилило противоречия между коренными европейцами и иммигрантами-мусульманами ${ }^{15}$. Это сводят на нет результаты интеграции иммигрантов-мусульман в европейское общество и приводит к усилению позиций радикального политического ислама.

Вместе с тем, успех мусульман в политической сфере носит фрагментарный характер и пока еще рано говорить об успехах вертикальной исламизации, а представительство мусульман в органах государственной власти стран Западной Европы имеет в основном символическое значение. В свою очередь, горизонтальная исламизация может оказывать сильное влияние на государство «снизу» при помощи сети исламских организаций и общественных институтов. Напр., Европейский институт гуманитарных наук, обучает современное поколение европейских мусульман классической исламской мысли. Его головное здание располагается в Шато-Шинон (центральная Франция) и имеет филиалы в Париже, а также в Лампетере (Великобритания). Федерацией также основан Европейский совет по фетвам в Дублине (Ирландия).

Горизонтальная исламизация приводит к расширению сферы влияния сетевых исламистских организаций и движений как умеренной, так и радикальной направленности, что способствует институционализации политического ислама.

Среди применяемых европейскими государствами инструментов «мягкой силы» важная роль отводится использованию Интернета:

${ }^{15}$ Н.А. Медушевский, Миграционный кризис в Европе через призму статистических данных, «Власть» 2017, Т. 25, № 11, с. 169-172. 
социальные сети, блоги, форумы, интернет-платформы и др. Это обеспечивает наибольший охват аудитории при минимальных затратах. В качестве примера можно привести несколько интернет-платформ, направленных на распространение принципов умеренного ислама:

«Annaqed» (Анакед - критик) ${ }^{16}$ - сайт для распространения светских ценностей среди мусульман. Он был изначально задуман как форум для арабоязычных жителей США. С тех пор был добавлен раздел на английском языке, при этом арабский раздел считается довольно популярным в странах Ближнего Востока.

«Middle East Transparent» ${ }^{17}$ является еще одной интернет-платформой на арабском, английском и французском языках. Хотя он не носит открыто светский характер, но предоставляет площадку либеральным мыслителям и представителям интеллигенции из различных регионов для выражения своих взглядов. На данном сайте также публикуются статьи и документы западных аналитиков и исследователей.

«Free-minds» ${ }^{18}$ - саудовский веб-сайт с несколько эксцентричным уклоном. Он позиционирует себя как ведущая интернет-платформа по распространению ценностей «истинного ислама», где обсуждаются вопросы социальных прав, статуса женщин, межконфессиональных отношений и наказания за отступление от норм шариата, что на самом деле служит прикрытием более либеральной позиции, не имеющей ничего общего с ортодоксальным исламом. На сайте подвергаются сомнению пять столпов ислама, напр., Шахада, которая не рассматривается как надежное свидетельство веры. Веб-сайт также включает в себя карту мира, на которой посетитель может выбрать нужный регион и просмотреть список зарегистрированных там активистов.

«Qantara.de» ${ }^{19}$ - это веб-сайт, финансируемый правительством Германии в рамках сотрудничества по американско-ближневосточной партнерской инициативе (MEPI). Данный сайт не занимает однозначно либеральных позиций; это форум, где могут быть представлены и консервативные взгляды (напр., в дискуссиях по поводу ношения хиджаба). Тем не менее, данная интернет-платформа направлена на развитие культуры энергичной дискуссии, где предпочтение отдается либеральным и светским взглядам. Сайт позиционирует себя как «мост» для установления межкультурного диалога между западным и исламским миром.

\footnotetext{
${ }^{16}$ Annaqed (The Critic), http://www.annaqed.com/en/about-us, дата обращения 11.03.2018.

${ }^{17}$ Middle East Transparent, http://middleeasttransparent.com/en/, дата обращения 21.04.2018.

${ }^{18}$ Free-minds, http://www.free-minds.org/, дата обращения 11.03.2018.

${ }^{19}$ Qantara.de, http://en.gantara.de/, дата обращения 11.03.2018.
} 
Также необходимо отметить, что в Западной Европе не существует единой, универсальной модели взаимодействия государства и религиозных объединений, т.к. процесс секуляризации имел разную степень интенсивности в данных странах ${ }^{20}$. Тем не менее, можно выделить базовые принципы светскости (закрепленные на международном уровне), в число которых входят свобода мысли, совести и религии, выступающие неотьемлемыми правами и свободами человека. С целью обеспечения защиты данных прав и свобод на протяжении XX в. был принят ряд международных документов, а также созданы соответствующие институты для контроля за их соблюдением ${ }^{21}$.

Правительства западноевропейских стран вырабатывают стратегии по противодействию радикализации мусульман. Но, в отличие от мусульманских стран, где проблема радикализации населения рассматривается через призму религии, европейские правительства воспринимают её как социальную проблему, связанную с неудачной интеграцией иммигрантов-мусульман. Европейский подход характеризуется двумя особенностями ${ }^{22}$ :

1) Отсутствие общего политического консенсуса относительно инструментов силового воздействия при решении проблемы. В этом отношении действия правительств значительно варьируется в той или иной стране и в целом носят бессистемный характер.

2) В идеологическом плане светские государства придерживаются косвенного подхода в борьбе с радикализацией мусульман. Они поддерживают исламские неправительственные организации, которые, по их мнению, обладают достаточным авторитетом среди мусульман, чтобы снизить риск радикализации. В этой связи остается открытым вопрос о выборе надежных союзников, которые бы действовали в интересах не только мусульман, но и государства в целом.

\footnotetext{
${ }^{20}$ B.А.Суворова, Миграционный кризис в Европе: проблемы вынужденной миграции, «Власть» 2018, Т. 26, № 1, с. 176-179.

${ }^{21}$ В.Г. Барановский, В.В. Наумкин, «Мир верь» и «мир неверия»: экспансия и редукция религиозности, «Полис. Политические исследования» 2018, № 6, с. 8-31, https://doi.org/10.17 976/jpps/2018.06.02, дата обращения 11.09.2019.

${ }^{22}$ A. Rabasa, S.L. Pettyjohn, J.J. Ghez, C. Boucek, Deradicalizing Islamist Extremists, // RAND, National Security Research Division, Santa Monica 2010, c. 121-123.
} 